\title{
Broadening Sustainable Development in Praxis Through Accountability and Collaboration
}

\author{
Mago William Maila \\ University of South Africa, Pretoria \\ South Africa
}

\section{Introduction}

In discussing the four different interpretations of the moral imperative to promote sustainable development, Hattingh (2002, p.14) says in his conclusion about the importance of sustainable development, informed by critical reflexive action, that "any interpretation of sustainable development functions as normative ideas. Such a set of normative ideas can function as guidelines for personal actions and as a baseline in terms of which governments, industry, commerce, consumers and citizens can be held accountable for their actions". As various stakeholders in this debate strive to interpret sustainable development within normative parameters, they need to ground their understanding and implementation strategies of sustainable development guidelines, in critical, reflexive processes of their practice, informed by their theory that guides their practice and action-in-practice that guides their theory. Such a process is pluralistic and collaborative and demands accountability. This chapter therefore, seeks to critically and analytically explore the grounding of sustainable development in praxis as a social, and reflexive informed process directed by collaboration and accountability imperatives.

Praxis is normally equated to practice and theory in social research investigations. A simple clarification of what practice and theory entail, is that practice involves a process-oriented action, and theory involves principles that guide action. May (2005) reaffirms the above notion about practice and theory. He sees the two concepts as simply two sides of the same coin, and he further argues that

"Theory aims at the production of thoughts which accord with reality. Practice aims at the production of realities which accord with thoughts. Therefore common to theory and practice is an aspiration to establish congruity between thought and reality (May, 2005, p. 339)."

In this chapter I theorize about the notion of grounding sustainable development in congruous aspirations of thought and reality within a broader perspective of praxis. However, I intend discussing the role of praxis in this investigation, further down in the chapter. I shall however, turn to accountability and collaboration as obligatory guidelines for both action in development and action in holding governments and civil society structures accountable to sustainability processes within their mandated portfolios.

Sustainable development initiatives need to be built on meaningful partnerships. In such partnerships, principles of accountability and collaboration are but few of the many 
principles critical in development processes. According to the Catholic Agency for Overseas Development (CAFOD), (2002), the agenda for accountability should be at the foreground of all development processes and the wellbeing of people. To the CAFOD, accountability involves among other things that: the fundamental principle of good governance for a government of a country is to first and foremost be responsible to its people; formal and inclusive monitoring processes be established; and mutual accountability regarding impoverished people be built between governments and donor communities (www.cafod.org.uk/policy_and_analysis/). The crux of this principle is that an inclusive process is imperative for productive partnerships between governments, civil society groups, impoverished communities and the wider community in development initiatives if sustained and meaningful outcomes are envisaged. Needless to mention that, partnerships as collaboration, must be underpinned by commitment, ownership, mutual learning, agency and transparency. I see these underpinnings as tenets of the two principles framing the discussion of this chapter.

Accountability and collaboration call all people to acknowledge both positive and negative causes and effects of their actions, that is a call to, being able to account for one's actions being responsible for one's doings (Thompson, 1995, p. 10). Reeves (2002) however, cautions that accountability is fraught with danger, but rife with opportunity. Danger in neglecting and marginalizing various communities' other ways of knowing; undermining environmental ethical issues and opportunity for engaging collaboration processes in sustainability matters in order to ensure economic growth that does not compromise the environment and the wellbeing of people. A positive promise by Markandya, Harou, Bellu and Cistulli (2002, p. 15) and, Fien and Tilbury (2002) is the historical document signed at Rio - Agenda 21, by nations of the world, committing themselves to promoting sustainable development through a great variety of transformative educational means, including nonformal, informal and primary and secondary education.

The Millennium Development Goals (2000), World Summit on Sustainable Development (2002), World Declaration on Education for All (1990), the Dakar Framework for Action for Education for All (2000), the Johannesburg World Summit on Sustainable Development (2002), the United Nations Decade of Education for Sustainable Development (2004) are some of the global means put in place to assist nations of the world to better the lives of all people. These global agreements and programmes meant mainly for local implementation processes are also pointers of what the world needs to do in order to address issues of sustainability and poverty eradication.

The understanding that natural resources should be used for the advancement of all people and the eradication of poverty, is founded on the ideal of a democratic world citizenry, primarily loyal to human beings the world over, and whose national, local, and various group loyalties are considered distinctly secondary (Nussbaum, 1998, p. 9). Although this view is seen by some scholars as encouraging 'laziness' and the ability to rely/depend on other people's mercy for survival (Hardin, 1990), the United Nations (UN) and other global initiatives that are worldwide focused to alleviate and eradicate poverty and health-ills through sustainable development programmes, seem to be convinced otherwise. The argument I advance in this chapter therefore, is that sustainable development is integral to economic and human development initiatives (Bell \& Morse, 2003) and that it must be embedded in the work human beings do, that is in praxis (Carspecken, 2002). Reiterating the 
view on the necessity of economic and human growth, Markandya, et al (2002, p. 17) maintains that the quality of economic growth should eradicate poverty over time as the ultimate criterion of sustainable development. Just note that the term sustainability is often used synonymously with sustainable development (Bell \& Morse, 2003, p. 3). In this chapter these terms are also used interchangeably.

Note that this chapter starts with a brief introduction illuminating on the discussion of the chapter, followed by a critical exploration and analysis and a suggestion for a better understanding and use of the varied perspectives of sustainable development. Thereafter, I explore an illumination on the links/linkages between theory and practice, praxis and sustainability, with a view to establish and promote interconnectedness and multiplicity of knowledges and knowings, will ensue, followed by a brief discussion on how sustainability research could endeavour to ground sustainability in praxis. Lastly, the chapter discusses partnerships and collaboration processes as underscored by accountability and responsibility in/for sustainability.

\section{Varied perspectives}

Complex and different views advanced by various scholars about sustainable development as a global trajectory relating to social justice, political justice, trade justice, environmental justice, are contested every day. There is also skepticism when it comes to why humanity needs to develop sustainably (Neefjes, 2000, p. 44). Nations in the North seem to be suspected of using their economic power to demand compliance to issues of sustainability, when in actual fact they are eying the abounding natural resources of the South. The South is also suspected of using its inability to develop sufficiently to uplift itself out of poverty and health-ills, and using the dependency-syndrome as leverage for arguing for more donor funding (Hardin, 1990).

It is for that reason that, defining sustainable development is not simple and easy. As indicated by Neefjes (2000), sustainable development is a complex, broad and vague concept. Neumayer (1999) concurs with Neefjes' observation. Adding to this problem is the fact that sustainable development is a contextually based operationalized activity, with an internationalized mandate (Johannesburg World Summit on Sustainable Development, 2002). Hence, it is described both in terms of historic-cultural dispositions and theoretical dispositions. The complex and diverse environmental problems and risks emerging worldwide as a result of development are seen as the cause of the new approach to development - sustainable development (Hall, 2000a). Reiterating this fact Hall (2000, p. 14) argues that "past patterns of development, especially those based heavily on the use of energy-intensive inputs are destructive of soils, biota, and systems of production, so that new approaches that focus instead on the long-term maintenance of the productive system should be the goal".

Bell and Morse (2003, p. 3) succinctly point out that sustainable development is all about an improvement in the human condition. They further distinguish sustainable development from other approaches that endeavour to improve the quality of human life, but does not emphasize economic growth, nor do they focus completely on people, "but more on the underlying philosophy that what is done now to improve the quality of life of people should not degrade the environment (in its widest bio-physical and socio-economic sense) and resources such that future generations are put at a disadvantage" $(2003$, p. 3). 
Goodland and Daly (1996) and Markandya, et al (2002) maintain that classically sustainable development is broadly portrayed as an interface between environment, economic and social sustainability. As already mentioned that the term sustainability is often used synonymously with sustainable development (Bell \& Morse, 2003) and that in this chapter these terms are also used interchangeably, hence, Markandya, et al $(2002$, p. 17) argue that sustainable development needs a new science of 'sustainomics - this refers to the new science of sustainable development as a trans-disciplinary and multidisciplinary approach. According to Munasinghe (1993) this approach requires a mixture of skills and disciplines.

Such an approach seems to be quite broad in its inclusion of knowledge from a diverse skills and disciplines, it projects a more neutral image which focuses attention explicitly on sustainable development, and avoids the implication of any disciplinary bias or hegemony (Markhandia et al., 2002, p. 18). Neefjes (2000, p. 49) argues that the three dimensions of which sustainable development is founded (economics, social, environment (diverse skills and disciplines) are supposed to be underpinned by environmental sustainability, which is anthropocentric in nature, primarily concerned with human welfare. However, regarding sustainability, all the scholars referred to above concur that politics is the line of the sustainable development discourse. I refer to this process as political sustainability that undergirds development.

Different intellectuals' understand development differently. Hall (2000, p. 14) points out that development means the increased exploitation of resources with the use of fossil energy, and it is by definition not sustainable, because fossil fuels are finite since they are not being made today on any important scale. Other stock resources, including especially soils and many minerals, also fossils, water, many forests, and fishes, are likewise essentially being mined and used once. By this chain of logic one might conclude that sustainable development is an oxymoron, a phrase that is internally inconsistent, such as jumbo shrimp'. On the other hand perhaps new technologies can decouple development from resource exploitation and the use of nonrenewable resources.

Eisgruber (1993, p. 4) contest that sustainable development is development that "... is taken to mean a positive rate of change in the quality of life of people, based on a system that permits the positive rate of change to be maintained indefinitely". Our Common Future (1987, p. 4) defines sustainable development as development that meets the needs of the present without compromising the ability of future generations to meet their own needs". Again, the emphasis is not just sustaining development for the sake of consumerism and the greedy amassing of wealth tendency by those who have the power resources to do so, but development that provides opportunities and for all people to advance in their wellbeing.

Caring for the Earth (1991, p. 10) concurs with the views of Eisgruber (1993) and Our Common future (1987) that perceives sustainable development as that which "improves ... the quality of human life while living within the carrying capacity of supporting ecosystems". However, this view largely depends on the kind of actions that people take in the environment regarding the sustenance of their lives, and that these are critical if sustainability is to be maintained. Neefjes (2000, p. 42) argues that sustainable development "requires meeting the basic needs of all people and extending to all the opportunities to fulfill their aspirations for a better life". If the people of the world are to respond positively to halving the poverty of impoverished 
masses, then it should be 'all hands on deck' as far as achieving this Millennium Development Goal. Nations that have more than enough resources should start and continue to play their role in ensuring that the environment is protected (Neefjes, 2000; Carter, 2001).

Those nations who are impoverished are not off the hook regarding their role in sustainability. They need to ensure that they do not take support for granted, but that support is to be accounted for in a transparent and responsible manner, by ensuring that graft does not undermine the goals of such support in all practices of sustainability. Since the understanding of practice as praxis is a critical strategy in the 'application' of programmes, especially initiatives that are focused to 'support', or foster development programmes, I need to discuss the central thoughts of this strategy within the notion of theory, practice, praxis and sustainability, and point out how the linkages of these can enrich sustainable lifestyles and human wellness.

\section{Theory, practice, praxis and sustainability: What are the links?}

Does it actually matter what comes first - theory or practice? Yes it does matter, depending whether the research action is based on a deduction or induction approach. May (2005, p. 32) argues that when we consider a general picture of social life and then research a particular aspect of it to test the strength of the theory, that is deduction research and that, theorizing comes before research (2005). On the other hand, when a researcher examines a particular aspect of social life and derives a theory (-ies) from the resultant data, that is known as induction. In this case research comes before theory and seeks to generate theoretical propositions on social life from the data (May, 2005, p. 32).

In order to understand the notion of grounding sustainable development in praxis, I must briefly explain how praxis is different than just practice, as both terms refer to action undertaken regarding a research or just a development endeavour. Some people see praxis as practice or research action. Praxis is more than just an action-in-practice, it involves the continuous reflection on ones work, understanding one's work through critical reflection in/on that work, and being critical involves scrutinizing the theories within one's practice, and the social structures that shape them (Janse van Rensburg, 1998, p. 39). Janse van Rensburg and Le Roux (1998, p. 104), reiterate that, praxis implies a conscious recognition of the relationship that exists between practice and its rationale(s), and that praxis constitutes deliberation on the 'why' question that illuminates meaningful resonance amidst the 'what' and the 'how of one's work (Janse van Rensburg \& Le Roux, 1998, p. 104). In the context of a research project it involves asking why we do things the way we do, and this questioning affects what we do next (feed back into the practice). In short, this means that action-inpractice, reflection and praxiological curriculum are the constitutive elements of praxis.

Now, whether theory comes before practice or practice gives rise to theory, the crux of the matter is that the research action or practice must be informed by critical reflexive reflection and praxiological curriculum as constitutive elements of the undertaken practice. Carspecken (2002) reiterates this notion of praxis as embedded within the actions of humanity. Looking at praxis in culture, he argues that action is not determined by structure, but it is rather conditioned by cultural milieu and is always productive of new cultural forms (2002, p. 60). He further observes that, "human beings are strongly motivated to continuously produce themselves" (2002, p. 62). 
According to Carspecken, Hegel's philosophy explains how human beings continuously 'produce themselves', through Geist as the agent of praxis, which is the impetus, process, and product of its own self-production. According to Marx (cf Carspecken, 2002, p. 63) selfproduction is located within the work humans do. This means "humans work to produce useful objects is simultaneously human work to produce themselves". All human beings need to produce themselves through praxis, or the praxis needs. However, realistically, these needs might be denied to them by the capitalist relations of production processes (Carspecken, 2002, p. 64). For praxis needs to be realized certain social conditions are mandatory. These are the control of the conceptualization of production; the control of the tools and resources used for work, and the control of the product in question (2002, p. 64). Let me now unpack this broad view of praxis as practice embedded in the actions of human beings - and how it relates to sustainable lifestyles that are meaningful for improving the quality of human life for present and future generations:

\subsection{Need for human beings to produce themselves}

Sustainability is a human activity. The unhealthy (overuse, over-exploitation, degradation of natural resources, etc) use of natural resources is a resultant of human beings' actions based either on accelerating profits in the name of development or simple greediness. However, sustainability that is based on engaging and focused on the participation of all people in its processes fosters a better understanding of people themselves and their actions - their practice. It is in the collaboration and engagement with sustainability processes that they see their actions. Those left out become strangers and suspicious of sustainable development.

\subsection{Need for human beings to produce worthy goods}

Sustainability is about ensuring a better quality of life for all. Goods and services are fundamental to all people's lives. Denying people goods and services is unethical- if people are unjustly marginalized and inhumanly treated the very goods and services produced are probably inequitably provided. So, all social injustices, be it trade injustice, social injustice, political injustice, trade injustice, environmental injustice, economic injustice, push the masses to the peripheral of sustainable development processes. The worthiness of them producing worthy goods and services is marginalized, compromised and denied. Meaning that they end up not been part of sustainable development praxis. Remember that praxis is not just practice, but it is practice that seeks informed actions based on continuous reflexive reflection and reshaped actions.

\subsection{Need of human beings to overcome challenges and obstacles that deny one to realize needs of self-production}

We many a time say "practice makes perfect", attesting to the fact that being involved in 'action' is better than being 'told' about the action. Those masses participating in sustainable development initiatives or programmes are better positioned in understanding the need to use resources wisely in the present (now) in order to ensure that the future will also be well taken care of. 
Not only do people need to produce themselves through praxis needs but, they also need to ensure that they overcome, minimize and eradicate those factors that either deny, or diminishes their chances of realizing their praxis needs. They therefore need to consciously ensure that they understand their actions- in - practice; they need to know and understand how they want to produce themselves; they need to deliberately collaborate their actions and be prepared to be continuously informed by their critical reflections in practice. This process of praxis calls for all people to participate in sustainability actions, and to ensure that factors working against sustainable development are overcome through either minimization or eradication processes. Throughout the processes of praxis resources are critical in ensuring that desired positive outcomes are possible. Hence, resources in the sustainable development action- chain cannot be misused or grafted. Marginalizing human beings in sustainability is equal to the misuse of human resources, and it is just as bad as misusing the employed in their line of duty. Graft is bad, whether practiced by recipients of donor funds or practiced by donors themselves.

A balanced and holistic approach to uprooting these ill practices in praxis should be based on robust anti-corruption strategies, based on international agreements on issues of social justice, political justice, economic justice, environmental justice and human rights and fair practices among donor (countries) and recipients (countries). Normally the term donor refers only to oversees government/NGO/ or company donating some sum of money for a specific development project or activity. However, a broader understanding of this concept should actually refer to both local and abroad donors, be they government, NGOs or industries. Graft is 'graft' whether the money being corrupted is oversees money or local. The result of such deeds is that development is seriously compromised or undermined. The CAFOD (http://www.cafod.org.uk/policy_and_analysis/policy_papers/) policy document seems to offer a better anti-corruption strategy in this regard in order to ensure better sustainability processes:

- Donors must complement ... initiatives to establish peer reviews by setting up independent assessment mechanisms for monitoring donor performance. The set independent body should judge donor performance against agreed upon principles of donor and recipient country accountability.

- Such agreed upon principles should foster local control, priority and ownership of aid programmes and enhance donor responsiveness and accountability to local parliaments, civil societies and taxpayers. Of course, donors must also be accountable to their countries abroad.

- Donors and governments should conduct a review of the effectiveness of anti-corruption institutions and anti-corruption conditionalities and build greater local civil society organizations participations, parliament and press in shaping the anti-corruption agenda.

- International anti-corruption agreements (such as the OECD Bribery Convention) must be strengthened and be supported by all governments.

- Binding commitments must be for the pro-active enforcement of regulations that close loopholes for bribes and open offshore bank accounts for the recovery of corruptly gained assets. Graft should not be allowed to determine the wellbeing of those who need donor support. 
- In countries with a high incident of corruption, development assistance still has a role to play. It should by-pass corrupt institutions and support, countervailing, anti-corruption influences.

- $\quad$ There should be enhanced investment in civil service reforms that prioritize local ownership and finance adequate pay scales for civil servants.

- Governments should ensure that democratic and participatory guidelines are at the heart of standards of good governance.

- An emphasis should be placed on participatory forms of governance in budget and poverty monitoring processes.

- Institutions such as the World Bank and the International Monetary Fund should be reformed in order to ensure that developing countries have a greater voice and influence in the shaping of policies that impact on their lives.

These anti-corruption strategies ideas map out a clear desire to ensure that action in praxis continues to be informed by reflexive, and collaborative decision-making processes, and less by selfish and arrogant inclined decisions. Development actions must be owned by all those meant to be assisted and supported in order to defeat and move out of their poverty status. And those with the capability should continue to ensure that necessary resources are just as mandatory to the attainment of sustainability life styles. Because corruption undermines such endeavours, all people should be called to participate with a renewed energy and determination to fight the scourge of corruption. Such a resolve is not discreet but is pluralistic, ongoing and aggressive collaboration for sustainability.

\section{Embedding sustainability in praxis - Is it self explanatory?}

I do not believe it is self-explanatory. This kind of action for sustainability cannot be taken for granted and be assumed. Reflexivity in sustainable development processes is supposed to be a deliberate activity, and focused on a rigorous process of improving the lives of all people through reflexive sustainability processes. For that reason, such reflexive action taking processes must be grounded in what people are 'actually-doing' to better the quality of life they want to enjoy. Such actions to be based on deliberate participation processes in matters that impact on their lives.

\subsection{Praxis as informed reflexive action in sustainable development processes}

Feedback is critical in informing the next step(s) of action in order to ensure maximum utilization of resources and successful achievement of outcomes. Reiterating this observation Lotz-Sisitka $(2006,20)$, points out that involving people in sustainable processes means that

- $\quad$ participatory approaches and methods are deliberately encourage and further develop in ways that are meaningful to all participants;

- integrated approaches and solutions to poverty, environmental degradation, health risks and other sustainable development challenges, are viewed as legitimate approaches just like educational practice;

- the need to involve people in questioning and critically evaluating the appropriateness of environmental and sustainability education practices is encouraged

- the need to involve people in questioning and critiquing the appropriateness of economic, political, bio-diversity sustainability education practices is mandatory 


\subsection{Praxis enabling participants to self-production}

As a human activity, sustainability ought to engage all people in its processes in order to foster a better understanding of themselves and their actions - their practice. Whether through formal, non-formal or informal education, and whether through government and business enterprises. All people must be involved in order to actualize themselves. Otherwise, if left out, they will become 'strangers to sustainable development' and suspicious to sustainability programmes. According to Lotz-Sisitka (2006), and Moore and Masuku-van Damme (2002) active participatory and people-centred methodologies cannot be overemphasized in sustainability processes. Hence, dealing with complex and uncertain issues, needs people to be involved on personal care levels in order to amicably and appropriately resolve these issues.

\subsection{Praxis as a producer of worthy goods and services}

Goods and services are basic to all people's lives. For that reason, all people must participate in sustainability programmes that endeavour to enable them to access resources. Unjust and inequitable processes in these programmes that marginalize impoverished communities are to be avoided at all cost. Praxis is not just the action we take in our practice, but it is practice that is based on informed continuous reflections on our actions as we participate using all resources available to us. This observation concurs with the environmental principles adopted at Rio De Janeiro (Rio Declaration 1992) that

- development should be focused on sustainable natural resources use and sound management thereof;

- security of land and resource tenure is a fundamental requirement of sustainable natural resource management;

- long-term food security depends on sustainable natural resource and sound environmental management;

- technologies that are environmentally friendly, socially acceptable should be developed and disseminated for effective use of natural resources;

- facilitating the creation of opportunities for communities and individual resource managers to manage their own natural resources and the environment sustainably should be encouraged

\subsection{Praxis as ongoing reflection in sustainable development processes}

As participants continue to ask the 'why' and 'how' questions of their practice, they gather information that not only helps them to shape actions, but also to be able to avoid activities and processes that will result in failure and cumbersome challenges. In this regard, I concur with Lotz-Sisitka (2006: 29) that there is great need for research to

- advance the conceptual, theoretical and methodological development of environment and sustainable development;

- strengthen and extend existing environment and sustainability education pedagogies, their relevance in society and their reality congruence;

- strengthen and extend the effectiveness and value of partnerships and networking processes; 
- strengthen curriculum development approaches and implementation strategies for mainstreaming environment and sustainable development concerns into education systems;

- inform work-based learning and new approaches to training and professional development to strengthen reflexive practice;

- develop strategies that can address complexities and value based questions in the teaching and learning process in a context characterized by high levels of cultural and linguistic diversity

If praxis is action-oriented processes, then it means that participation and collaboration are inevitable, and such participation and collaboration also have to be grounded in accountability processes if meaningful outcomes are envisaged.

\section{Collaboration and accountability in sustainable development}

Collaboration is about various groups of NGOs, government, civil society and business coming together and deliberating on various strategies of action in/for sustainable development. Sometimes collaboration is used to refer to actions of 'conniving' and shoddy actions against individuals or operations. However, in sustainable processes, collaboration is about the coming together of various stakeholders with a view to participate at a 'broadknowledge-base', where all participation endeavours stand to gain. The conviction is that broad-based information 'think-tank' will ensure that the views of all (governments and civil society) are represented. I must say that it is assumed that participation and representation are strategies that are useful when applied effectively. As we know, participation can be 'shallow', tokenistic, and 'endorsement type (Maila, 2006) or can be instrumentalistic and functionalistic (Neefjes, 2000). On the other hand, representation can be (1) biased towards small, well-organized groups with few claims to represent the larger public, (2) undermined by offering opportunities for participation late in the decisionmaking process when proposals are already developed and accepted by the relevant agency (Tolentino, 1995, p. 142).

In order to either avoid or minimize the effects of the above types of representation through participation, Tolentino (1995) argues for not just participation in sustainable development, but for popular participation. He cites three convincing reasons why popular participation by civil society, business and government should be a requirement for development that is sustainable:

- A number of procedures in the EIA process provide opportunities for interested groups to inform agency deliberations about their concerns and preferences or to contribute formative ideas to the decision-making process.

- Sometimes, dissatisfied concerned citizens use available information to block proposals through protest or litigation.

- Suits are filed against government agencies for failure to regulate activities, which damage the environment and private industries for developing technologies in violation of environmental standards (1995, p. 142-143).

Tolentino (1995, p. 143) further cites other reasons that are constraints to the implementation of popular participation for sustainable development. These are poverty; illiteracy; 
inadequacy of political mechanisms; certain agencies of governments view environmental movements as obstacles to development; sometimes the state is the stumbling-block to development itself; absence of laboratories hampers civil society proving their case against environmental degraders and; copious resources of industries can ensure that they do not own up to their environmental ills.

Participation is also integral to democratic values and principles. People cannot be denied this democratic and human right under normal circumstances. Of course, sometimes this value and principle is arbitrarily practiced by those in positions of power, in that the necessity to have people interact with policy issues is ignored. Dryzek (2000, p. 1) argues that democracy is deliberative in its nature and

"As a social process is distinguished from other kinds of communication in that deliberators are amenable to changing their judgements, preferences, and views during the course of their interactions, which involve persuasion rather than coercion, manipulation, or deception."

Of note, is that participation in governance is a democratic right, but also an ethical right. It means that it is morally wrong to deprive people the right to exercise their choices freely in decision matters that impact on their lives. Governance that is ethically correct needs to take the masses on board in decision-making processes.

Good governance relies heavily on the needs of its masses. Civil society normally desires clean governance. No wonder, people throughout the world are rejecting the notion that corruption is inevitable (States News Service, 2006). The abuse of entrusted authority for private or personal enrichment is not acceptable as this undermines all initiatives by governments and nongovernmental organizations geared towards the advancement of society. Various strategies of how to curb corruption are put in place by various governments. For example, raising public awareness on the existence of the problem; helping poor countries develop transparent contracting and audit systems; enforce corruption laws; responding speedily to reports of suspected corruption; training staff to recognize signals of corruption in governments and nongovernmental organization development initiatives (States News Service, 2006). Although all of these strategies seem to be good and focused, their weakness is that they are mainly focused on developing countries and not the developed countries; and focuses on recipients and not the donor. So, any act or doing in corruption would not necessarily be picked up in developed countries' donor agencies, but rather, would squarely be blamed on the recipient and her/his country.

In such a complex situation, the World Conservation Strategy, which proposed the nine principles in Caring for the Earth (IUCN, 1991: 12) seem to provide us with a better lifestyle based on an moral standard for living/lifestyles, and these are

- respect and care for the community of life (an ethical principles defined as duty of care for other people);

- $\quad$ improving the quality of human life;

- conserving the vitality and diversity of the earth;

- minimizing the exhaustion of non-renewable resources;

- $\quad$ keeping within the carrying capacity of the earth;

- changing personal attitudes and practices, in accordance with an ethic for sustainable living; 
- $\quad$ enabling communities to care for their own environments;

- forming national frameworks for the integration of development and conservation;

- forming a world alliance to implement sustainability on a global scale

It must be noted however, that the success of the implementation of these principles in meaningful ways, depends on meaningful collaboration and accountability practices in sustainable development.

\section{Concluding comment}

Sustainable development is a universal peoples-centred policy initiated programme, mainly geared to sustain our environment, economics, and socio-cultural dimensions of life. No one is to be excluded in this programme if we are to change the lives of all people for the better. Hence, the grounding of sustainable development in praxis, continuous informed reflexive action in practice, is enabling participants to meet their praxis needs.

Sustainability initiatives cannot ignore the importance of all people participating in such initiatives. Communities must be part of collaboration initiated for sustainable development. Government, academia and business need to ensure that all participants adhere to both international and local agreed upon principles of rooting and avoiding corruption in sustainability programmes. For that reason, continuous research is imperative regarding the formative, monitoring and evaluation of sustainability processes. Theoretical knowledge and understanding of sustainable development must be a continuous process.

It must be continuous and be applicable to actions taken on the ground. It must direct what needs to be done. It must influence daily activities of governments and civil society and sustainability. However, conversely, it must be informed by actions that are locally, nationally and internationally situated. As sustainable development shapes actions, it is also shaped by its own actions. Therefore, sustainability programmes that marginalize the masses from participating in development initiatives are both ignorant of what they miss in sustainable development and praxis, and their actions are both irresponsible and dangerous to the environment economics, politics, socio-cultural and biodiversity enhancing lifestyles.

\section{References}

Bell, S \& Morse, S. (2003) Measuring sustainability learning by doing. London: Earthscan Publications Limited.

CAFOD (2002) Available at: www.cafod.org.uk/policy_and_analysis/.

Carspecken, P. F.(ed).(2002) The hidden history of praxis theory within critical ethnography and the criticalism/postmodernism, edited by Y.Zou and E.T.Trueba, in Ethnogrphy and School: Qualitative Approaches to the Study of Education. Lanham: Rowman \& Littlefield Publishers. Pp 55-86,

Carter, N. (2001) The politics of the environment: Ideas, Activism, Policy.

Goodland, R \& Daly, H. (1996). Environmental sustainability: Universal and NonNegotiable, in Ecological Applications, 6(4), pp 102-1017.

Cohen, G. A. . Karl Marx's Theory of History: A defense. Oxford: Oxford University Press.

Dobson, A. (1998) Justice and the Environment: Conceptions of Environmental Sustainability and Dimensions of Social Justice. Oxford: Oxford University. 
Dragun, A. K \& Jakobsson, K. M. (1997) Sustainability and global environmental policy: New perspectives. Cheltenham, UK: Edward Elgar.

Dryzek, J.S. (2000) Deliberative Democracy and Beyond: Liberals, Critiques, Contestations, Oxford: Oxford University Press.

Eisgruber, L.M. (1993) Sustainable development, ethics, and the Endangered Species. Choices (Third Quarter), Washington, D.C: U.S. Dept. of Agriculture, 4-8.

Fien, J., \& Tilbury, D. (2002) The global challenge of sustainability, in Education and Sustainability, D. Tilbury, R. B. Stevenson, J. Fien and D. Schreider (eds). Gland, Switzerland: IUCN, PP. 1-11.

Ginther, K., Denters, E \& DE Waart, P. J. I. M (eds). (1995) Sustainable development and good governance. Dordrecht: Martinus Nijhoff Publishers.

Goodland, R., \& Daly, H. (1996) Environmental sustainability: universal and non-negotiable. Ecological Applications, Vol. 6, No. 4, pp. 102-117.

Hall, C. A. S. (2000a) The changing tropics, edited by C. A. S Hall, C. L Perez \& G Leclerc, in Quantifying sustainable development: The future of tropical economies. San Diego: Academic Press.

(2000b) The theories and myths that have guided development, edited by C. A. S Hall, C. L Perez \& G Leclerc, in Quantifying sustainable development: The future of tropical economies. San Diego: Academic Press.

(2000c). The myth of sustainable development, edited by C. A. S Hall, C. L Perez \& G Leclerc, in Quantifying sustainable development: The future of tropical economies. San Diego: Academic Press.

Hall, C. A.S., Perez, C. L \& Leclerc, G (eds). (2000) Quantifying sustainable development: The future of tropical economies. San Diego: Academic Press.

Hardin, G. 1990 Living on a Lifeboat, edited by A. F Falikowski, in Moral philosophy: Theories, Skills, and Applications. Englewood Cliffs, New Jersey: Prentice Hall.

Hardin, G. (1990) 'Living in a lifeboat', in A.F. Falikowski (Ed.) Moral Philosophy, Englewood Cliffs, NJ: Prentice Hall.

Hattingh, J. (2002) On the imperative of sustainable development: Aphilosophical and ethical appraisal. In Janse van Rensburg, E., Hattingh, J., Lotz-Sisitka, H. \& O'Donoghue, R. (Eds), Environmental education, ethics and action in Southern Africa. EEASA Monograph. Pretoria: HSRC Press. pp. 5-16.

IUCN/UNEP/WWF (1991) Caring for the Earth: A Strategy for sustainable living. The World Conservation Union, United Nations Environment Programme and World Wide Fund for Nature, Switzerland.

Janse van Rensburg, E. 1998. The Educational Response to the Environmental Crisi. Unpublished Paper, Gold Fields Participatory Course in Environmental Education, Course File, Rhodes University Environmental Education Unit. Grahamstown: Rhodes University.

Janse van Rensburg, E. \& Le Roux, K. 1998. Goldfields participatory course in environmental education: an evaluation in process. Grahamstown: Rhodes University Environmental Education Unit.

Johannesbuirg World Summit on nSustainable Development 2002 United Nations Educational, Scientific, and Cultural Organization (UNESCO) 2004. United Nations decade of education for sustainable development 2005-14 Draft international implementation scheme, October, (2004). Paris: UNESCO. 
Lotz-Sisitka, H. 2006. Participating in the UN Decade of Education for Sustainability: Voices in Southern African consultation process, in Southern African Journal of Environmental Education, Vol. 23 (2006):10-33.

Maila, M. W. (2005) Environmental education as a human capability strategy for poverty reduction, Paper presented at the GRUPHEL Conference in Maseru, Lesotho, in November 2005.

Markandya, A., Harou, P., Bellu, L. G \& Cistulli, V. (2002) Environmental Economics for Sustainable Growth: A Handbook for Practitioners. Cheltenham: Edward Elgar.

May, T. 2005. Social research: Issues, methods and process. New York: Open University Press.

Moore, K., \& Masuku-van Damme, L. (2002) The Evolution of People-and-Parks Relationships in South Africa's National Conservation Orgarnisation, in Environmental Education, Ethics and Action in Southern Africa. EEASA Monograph. Pretoria: HSRC.

Millenium Development Goals. (2000a) Paris: UNESCO.

Munasinghe, M. (1993) Environmental Economics and Sustainable Development. Washington, D.C: World Bank.

Neefjes, K. (2000) Environments and Livihoods: Strategies for sustainability. Oxford: Oxfam. Neumayer, E. 1999. Weak versus strong sustainability: Exploring the limits of two opposing paradigms. Cheltenham: Edward Elgar.

Neumayer, E. 1999 Weak versus strong sustainability: Exploring the limits of two opposing paradigms. Cheltenham: Edward Elgar.

Nussbaum, M. C. (1998) Cultivating Humanity: A classical defense of reform in liberal education. Oxford: Oxford University,

Reeves, D. G. (2002) Holistic Accountability. Thousand Oaks, California: Corwin Press.

The States News Service (2006) 'Corruption can block economic development', Washington: States News Service.

Thompson, D. (1995) The Concise Oxford Dictionary of Current English, Oxford: Clarendon Press.

Tolentino, A.L. ( 1995) Guidelines for policiesand programs analysis for small and medium enterprise development. Research and Programmes Development Section, Entrepreneurship and Management Development Branch, Enterprise Development, ILO. Draft 5 May.

UNESCO. (2002) World Summit on Sustainable Development. Paris: UNESCO.United Nations Conference on Environment and Development (UNCED). (1992) Agenda 21. Rio de Janeiro: UNCED.

WCED. 1987 Our Common Future. Oxford: Oxford University.

World Declaration on Education for All. 2000a) Paris: UNESCO.

http://www.cafod.org.uk/policy_and_analysis/policy_papers/ 


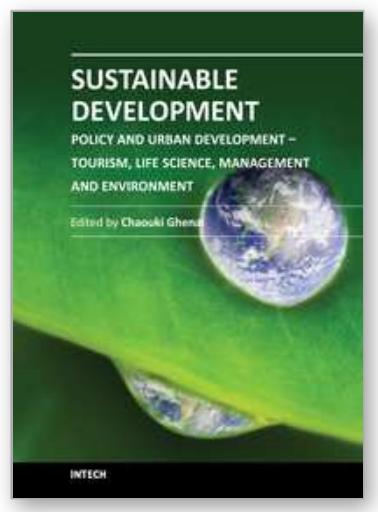

\author{
Sustainable Development - Policy and Urban Development - \\ Tourism, Life Science, Management and Environment \\ Edited by Prof. Chaouki Ghenai
}

ISBN 978-953-51-0100-0

Hard cover, 478 pages

Publisher InTech

Published online 24, February, 2012

Published in print edition February, 2012

The technological advancement of our civilization has created a consumer society expanding faster than the planet's resources allow, with our resource and energy needs rising exponentially in the past century. Securing the future of the human race will require an improved understanding of the environment as well as of technological solutions, mindsets and behaviors in line with modes of development that the ecosphere of our planet can support. Sustainable development offers an approach that would be practical to fuse with the managerial strategies and assessment tools for policy and decision makers at the regional planning level.

\title{
How to reference
}

In order to correctly reference this scholarly work, feel free to copy and paste the following:

Mago William Maila (2012). Broadening Sustainable Development in Praxis Through Accountability and Collaboration, Sustainable Development - Policy and Urban Development - Tourism, Life Science, Management and Environment, Prof. Chaouki Ghenai (Ed.), ISBN: 978-953-51-0100-0, InTech, Available from: http://www.intechopen.com/books/sustainable-development-policy-and-urban-development-tourism-lifescience-management-and-environment/broadening-sustainable-development-in-praxis-through-accountabilityand-collaboration

\section{INTECH}

open science | open minds

\section{InTech Europe}

University Campus STeP Ri

Slavka Krautzeka 83/A

51000 Rijeka, Croatia

Phone: +385 (51) 770447

Fax: +385 (51) 686166

www.intechopen.com

\section{InTech China}

Unit 405, Office Block, Hotel Equatorial Shanghai

No.65, Yan An Road (West), Shanghai, 200040, China

中国上海市延安西路65号上海国际贵都大饭店办公楼 405 单元

Phone: +86-21-62489820

Fax: $+86-21-62489821$ 
(C) 2012 The Author(s). Licensee IntechOpen. This is an open access article distributed under the terms of the Creative Commons Attribution 3.0 License, which permits unrestricted use, distribution, and reproduction in any medium, provided the original work is properly cited. 